\title{
Demersal fish community on the inner shelf of Ubatuba, southeastern Brazil
}

\author{
Gecely R. A. Rocha \& Carmen L. D. B. Rossi-Wongtschowski \\ Instituto Oceanográfico da Universidade de São Paulo \\ (Caixa Postal 66149, 05315-970 São Paulo, SP, Brasil)
}

- Abstract: Fluctuations in the distribution and abundance of demersal fishes collected by otter trawl on the continental shelf of Ubatuba were examined over a two-year sampling period, in an area up to $50 \mathrm{~m}$ depth. A total of 111 species were collected. Seasonal and annual fluctuations in species abundance were related to differences in the distribution of Coastal Water and South Atlantic Central Water masses. The demersal fish fauna in the area was divided into three ecologically distinct communities: Tropical Sciaenid, Subtropical Sciaenid, and Gerreid-Haemulid. The most important one is the Tropical Sciaenid Community, characterized by Ctenosciaena gracilicirrhus, Paralonchurus brasiliensis, and Cynoscion jamaicensis.

- Resumo: A distribuição e a abundância de peixes demersais na plataforma continental de Ubatuba, até $50 \mathrm{~m}$ de profundidade, foram examinadas durante dois anos. Foram coletadas 111 espécies. As flutuações sazonais de abundância estiveram relacionadas com a dinâmica das massas d'água. Três comunidades ocupam a área: Sciaenidae Tropical, Sciaenidae Subtropical e Gerreidae-Haemulidae, sendo a primeira a mais importante, dominada por Ctenosciaena gracilicirrhus, Paralonchurus brasiliensis e Cynoscion jamaicensis.

- Descriptors: Sciaenidae, Demersal fish, Community, Southwestern Atlantic.

- Descritores: Sciaenidae, Peixes demersais, Comunidades.

\section{Introduction}

Tropical ecosystems are highly complex and poorly studied. Data on the ecology of tropical fishes are scarce and mainly limited to studies of commercially important species. Before 1985 there were few reports. describing demersal fish communities from waters off Ubatuba, southeastern Brazil. A list of species was published by Nonato et al. (1983), Cunningham (1983) studied the ichthyofauna composition and its variations in some bays and islands of the area, and Braga \& Goitein (1984) described the biology of the common species off Anchieta Island. Since then Rocha (1990), Rossi-Wongtschowski \& Paes (1993) and Natali Neto (1994) have been studying different

$\overline{\text { Contr. no. } 816}$ do Inst. oceangr., da Usp. aspects of the demersal fish community, mainly related to composition, abundance, and diversity of species, as part of a broad interdisciplinary research program.

Little is known of the dynamics and organization of the Ubatuba ecosystem. This lack of information provided the impetus for a project developed in that area from 1985 to 1988 , with the purpose of understanding its structure and function (Pires-Vanin \& Matsuura, 1993; Pires-Vanin et al., 1993). As the trend for management of living resources moves from single-species to multispecies assemblages, it becomes increasingly important to encompass ecosystems as management units. As a contribution to that goal, this study describes seasonal variation in abundance and species composition of the demersal fish community on the inner shelf of Ubatuba. 


\section{Study area}

The area under study is located off the southeastern coast of Brazil (Fig. 1). Three water masses converge in the region: Coastal Water $(\mathrm{CW})$ $\left(\mathrm{T}>20^{\circ} \mathrm{C}, \mathrm{S}<36\right)$, South Atlantic Central Water (SACW) $\left(\mathrm{T}<18^{\circ} \mathrm{C}, \mathrm{S}>36\right)$ and Tropical Water (TW) ( $>20^{\circ} \mathrm{C}, \mathrm{S}>36$ ). During summer cold water (SACW) is often found in the inner portion of the continental shelf $(20-100 \mathrm{~m})$, while warm water $(\mathrm{CW})$ is found in a narrow band nearshore. It results in a vertical stratification over the inner shelf, with a strong thermocline at mid-depths. In the winter period when SACW is restricted to outer shelf, horizontal and vertical thermal gradients are reduced and almost no stratification is observed in the inner shelf (Castro Filho et al., 1987).

During autumn and winter, a cooling of the surface water and an intensification of vertical mixing processes, due to higher frequency of strong winds, cause an inversion of the circulation which destroys the seasonal thermocline observed in summer (Castro Filho et al., op. cit.). As a result, the water temperature in the bottom layer is higher in winter than in summer. The region can be divided into two domains based on its physical dynamics: interior and exterior. The interior domain is controlled by the wind, while the exterior, although influenced by the wind, is under the direct influence of the Brazil Current. The interior domain is limited by the coastline and the 40 to $50 \mathrm{~m}$ isobaths, and its width is about $50 \mathrm{~km}$. The exterior domain extends from these isobaths to the continental shelf break.

Sand and silt sediments predominate in the area. The southern inner shelf is more sheltered, by São Sebastião island, and strongly influenced by the continent. Closer to the shoreline, mud of continental origin and organic matter are deposited on the bottom. In contrast, coarser particles settle on the northern inner shelf and in offshore areas. Temperature-Salinity diagrams and the distribution of sediment grain sizes in the area were shown in Pires (1992).

The demersal ichthyofauna of the southern Brazilian shelf, transitional between tropical and temperate zones, is part of the Argentinean marine zoogeographic province, which extends between $22^{\circ}$ and $42^{\circ} \mathrm{S}$ (Figueiredo, 1981). Species with tropical and temperate water affinities of both northern and southern hemisphere and a series of endemic species overlap here.

\section{Material and methods}

Sampling was carried out on a seasonal basis, during a two-year period, from October 1985 to July
1987. Hauls were made at nine fixed stations, at depths of $15 \mathrm{~m}$ (stations 3,6 and 9), $30 \mathrm{~m} \mathrm{(2,5}$ and 8 ) and $50 \mathrm{~m}$ (1, 4 and 7) (Fig. 1). Fish were collected with an otter trawl, of $6 \mathrm{~m}$ mouth opening, $40 \mathrm{~mm}$ stretch mesh in the body and sleeve, and $25 \mathrm{~mm}$ bar mesh at the codend; each door was $1.0 \mathrm{~m}$ long, $0.5 \mathrm{~m}$ wide, and weighed $40 \mathrm{~kg}$. One-hour tows were made during daylight hours at a speed of 2 $\mathrm{kn}$, resulting in a swept area of $22,236 \mathrm{~m}^{2}$. Bottom water samples were collected $0.5 \mathrm{~m}$ above the bottom with Nansen bottles at each station prior to trawling. Water temperature, salinity and dissolved oxygen were determined.

In the laboratory specimens were sorted, identified, counted, weighed (nearest $0.1 \mathrm{~g}$ ) and measured (total length). The state of maturity was determined when possible.

Although the objective was to capture demersal species, a variety of pelagic species occurred as well. Because the gear was not designed to capture pelagic species effectively, they were excluded from the analysis to avoid bias.

The species which accounted for $90 \%$ of the catch in weight and number were considered dominants. These species were then ranked by importance, which was calculated by multiplying the frequencies in number, in weight and of occurrence.

The dominant species were grouped into assemblages. Canonical Correspondence Analysis (CCA) was performed using the program CANOCO (version 3.1) (ter Braak, 1990) to examine the relation between species, stations, and environmental variables. Only species present at more than $10 \%$ of the stations in every year were used for analysis. Weight data were log-transformed $[\ln (x+1)]$ prior to analysis. Within the CCA procedure, forward selection of the environmental variables and Monte Carlo permutation tests were used to test the significance of each environmental variable. The variables were further evaluated by examining intraset correlations (correlations between species axes and environmental variables). Data on depth, temperature, salinity, dissolved oxygen, organic matter, calcium carbonate, sand and clay content were tested.

\section{Results}

Seasonal isotherms are shown in Figure 2. Variations in salinity and dissolved oxygen were taken into consideration for classifying water masses. Salinity values showed a small variation (34.96 to $35.93 \mathrm{ppt}$ ) and oxygen was frequently over $70 \%$ of saturation. 


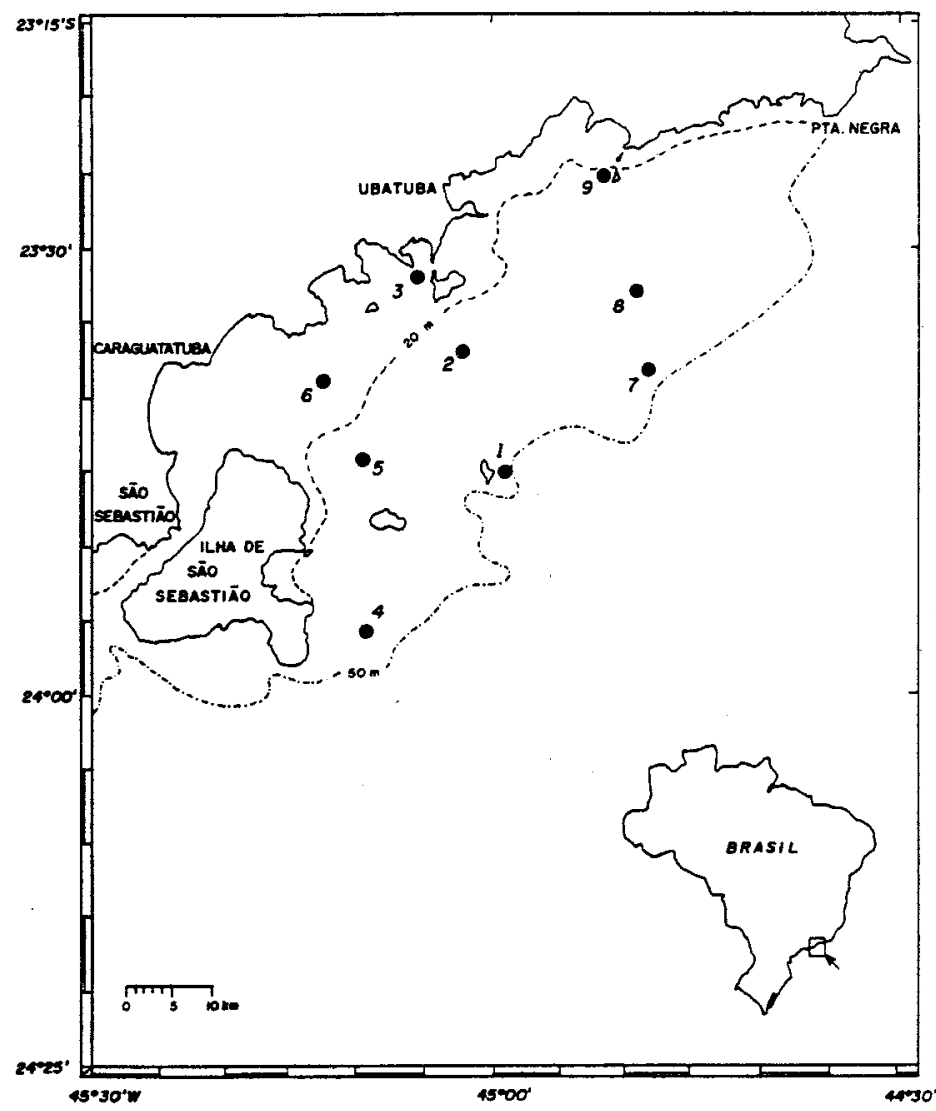

Fig. 1. Study area in the south-eastern Brazilian shelf showing sampling stations (1 to 9).

A total of 43 families comprising 111 demersal fish species was collected during the twoyear sampling period (Table 1). Sciaenidae was the most abundant family both in number of species (18) and individuals $(62.6 \%)$. The number of species and the abundance in number of individuals and weight by season are in Table 2. A great fall in abundance was observed on second sampled year, especially in autumn and winter. Twenty and twenty six species accounted for $90 \%$ of the total number and weight, respectively. After ranking, twenty-two species were abundant both in number and weight, which were considered as dominant (Table 3 ).

Both abundance and number of species were greatest in autumn. In both years the number of individuals increased from spring to autumn and declined in winter. Since samples were not replicated, differences could not be tested. Although in the first sampled year the weight in summer and autumn was very similar, the number of individuals in autumn was almost twice the observed in summer (Table 2, Figs $3,4)$. A few different species were found in autumn but they were not abundant. Most of the abundant species were present both in summer and autumn. So this difference could indicate a great entrance of juveniles in autumn. In fact, the length analysis showed a greater proportion of small individuals at this season. The same was observed in the second year, but in a smaller magnitude.

\section{Species distribution}

The distribution of the dominant species in relation to the environmental factors was examined. It is important to emphasize that these species have a wide geographical distribution, and only a small part of their population occupies the studied area.

Most of the dominant species were present throughout the year, with seasonal fluctuations in abundance (Figs 3, 4). Ctenosciaena gracilicirrhus and Paralonchurus brasiliensis were the most abundant species in the area. The former was widely distributed and occurred at temperatures between 18 and $22^{\circ} \mathrm{C}$. The latter was mainly associated with shallow waters, although it occurred up to $50 \mathrm{~m}$, at temperatures of 22 to $25^{\circ} \mathrm{C}$ (Fig. 5). Cynoscion jamaicensis was also distributed throughout the area, associated with the Coastal Water, and in sites with sandy-clay substrata. A more restricted distribution was detected during the second year. 


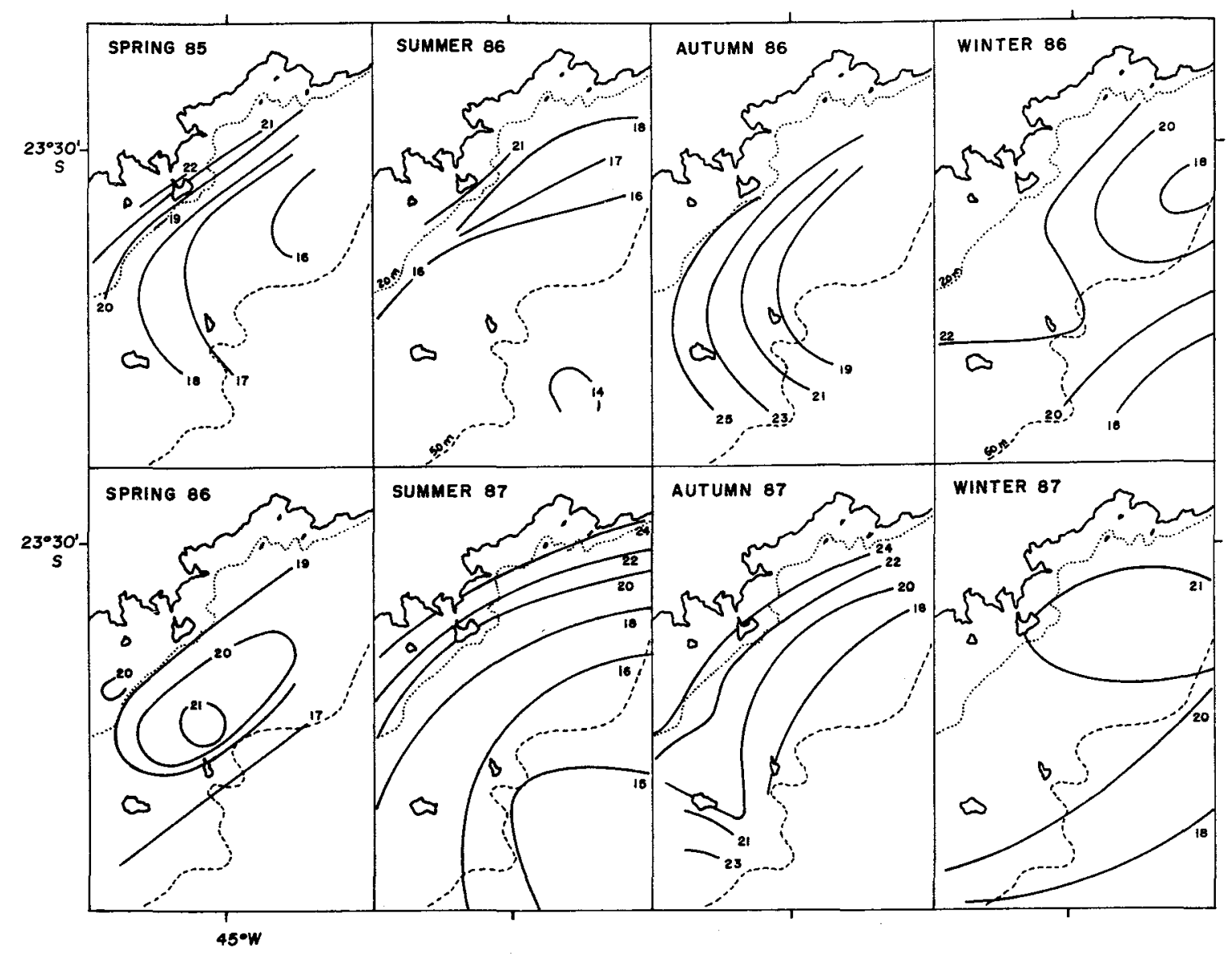

Fig. 2. Horizontal distribution of bottom temperature $\left({ }^{\circ} \mathrm{C}\right)$ in spring, summer, autumn and winter during 1985-87 period.

There was a remarkable decrease in the abundance of dominant species throughout the second sampled year (Table 1). However, since total catch was smaller in the second year, relative abundance did not show the magnitude of this decline (Table 3). Only a few species, such as Raja agassizii, Dules auriga, Psammobatis glansdissimilis, Pagrus pagrus, and Squatina guggenheim, showed an increase of abundance from one year to another.

Prionotus punctatus was the only species collected at all stations, in all seasons (Fig. 5), although its abundance changed greatly (Figs 3,4$)$. It occurred in sites with sand and sandy-mud sediments and at temperatures between 17 and $26^{\circ} \mathrm{C}$, mainly above $20^{\circ} \mathrm{C}$. Porichthys porosissimus was also widely distributed (Fig. 5) and was one of the few eurybathic species in the area, found on both inner and outer shelf up to $100 \mathrm{~m}$ depth (Natali Neto, 1994).

In contrast to Cynoscion jamaicensis, Cynoscion guatucupa was more frequent and abundant around $50 \mathrm{~m}$ depth (Fig. 5) during summertime. It occurred at temperatures from 15 to $18^{\circ} \mathrm{C}$, following the coastward movement of the SACW.

Raja agassizii was the third most abundant species in weight and also the most widely distributed of the skates present in the area. It occurred up to 50 $m$ depth (Fig. 6), in sandy sediments and at temperatures from 18 to $23^{\circ} \mathrm{C}$.

Other Sciaenidae species associated with warmer waters were Micropogonias furnieri, Menticirrhus americanus, and Isopisthus parvipinnis. The latter was more restricted to shallower stations. These species were most abundant in autumn and winter, occurring at temperatures from 16 to $26^{\circ} \mathrm{C}$, particularly between 22 and $24^{\circ} \mathrm{C}$.

Dules auriga, Etropus longimanus, and Paralichthys patagonicus were often found at stations $1,2,7$, and 8 (Figs 5,6), but were not restricted to them. They were more abundant in spring and summer, with influence of the colder SACW waters. They occurred at temperatures between 15 and $18^{\circ} \mathrm{C}$, over sand bottoms, with slightly different distributions. While the former was the most important species on the outer shelf, the second occurred mainly between 30 and $70 \mathrm{~m}$ depth, though it may be found as deep as $100 \mathrm{~m}$ (Natali Neto, 1994). The latter was a permanent species on the inner shelf, rarely found at stations deeper than $50 \mathrm{~m}$ (Natali Neto, op. cit.). 


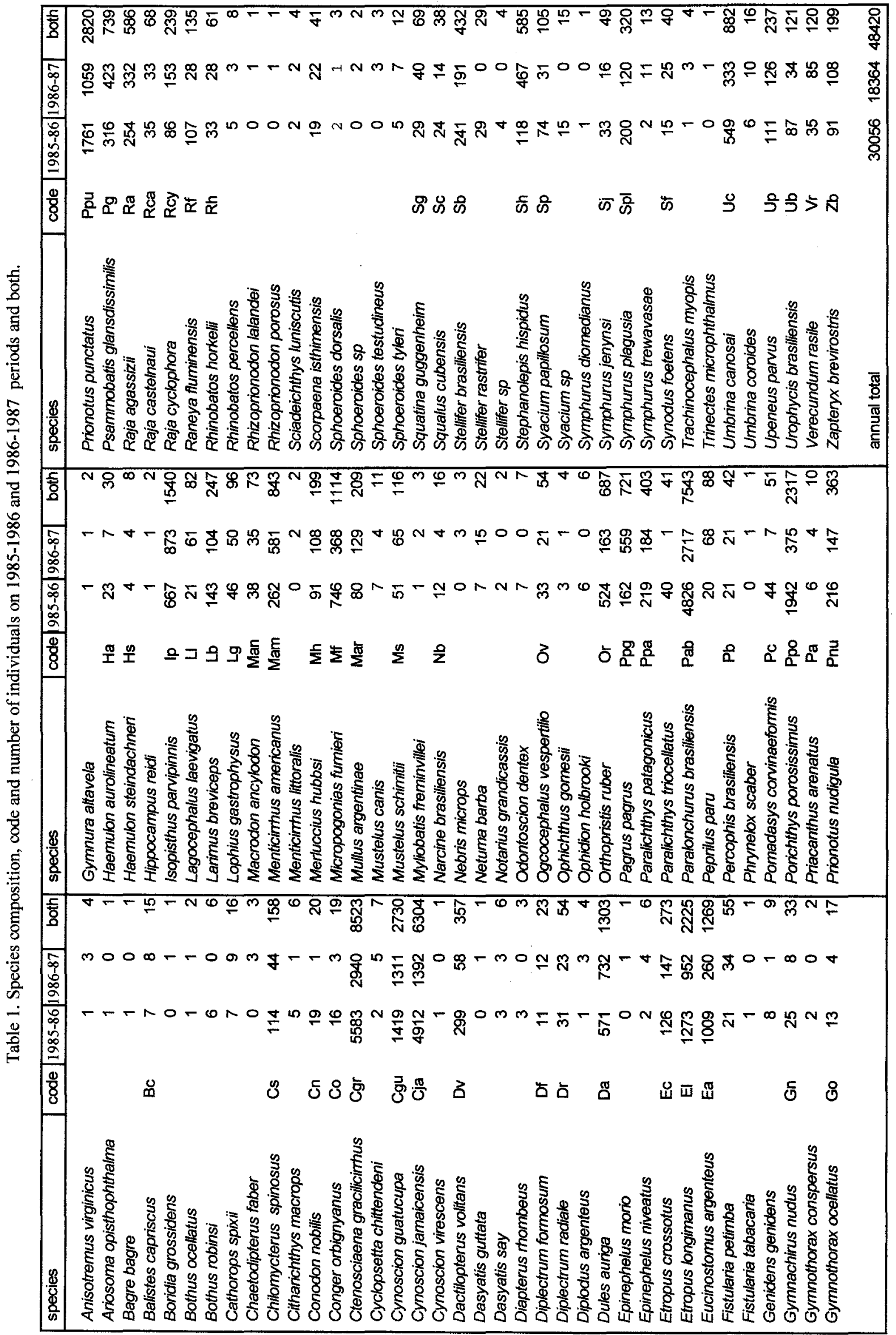


Table 2. Seasonal number of species (S), number of individuals $(\mathrm{N})$ and weight (W) in $\mathrm{kg}$ on $1985-86$ and $1986-87$ periods.

\begin{tabular}{lrrl}
\hline & S & \multicolumn{1}{c}{ N } & W \\
\hline 1985-86 & & & \\
Spring & 66 & 3692 & 215 \\
Summer & 55 & 6023 & 410 \\
Autumn & 75 & 11258 & 408 \\
Winter & 63 & 9083 & 330
\end{tabular}

1986-87

\begin{tabular}{llll} 
Spring & 68 & 2883 & 174 \\
Summer & 60 & 6009 & 361 \\
Autumn & 71 & 6075 & 272 \\
Winter & 66 & 3397 & 122 \\
\hline
\end{tabular}

Umbrina canosai inhabited the $40-70 \mathrm{~m}$ range and was also associated with the SACW. However, it was common only in summer. It occurred exclusively at stations around $50 \mathrm{~m}$ (Fig. 6) with temperatures from 16 to $18^{\circ} \mathrm{C}$.

Orthopristis ruber and Eucinostomus argenteus presented a similar distribution pattern, strongly associated with station 2 , and to a lesser extent, stations 8 and 9 (Figs 5, 6). They occurred over sandy-gravel sediments, up to $35-40 \mathrm{~m}$ depth, and were mainly associated with warm waters (18 to $25^{\circ} \mathrm{C}$ ). They were less common in summer.
Raja cyclophora, Psammobatis glansdissimilis, Squatina guggenheim, and Raja castelnaui did not occur at shallow stations $(20 \mathrm{~m})$ and were most abundant near $50 \mathrm{~m}$ depth (Fig. 6). They occurred over sand and sandy-mud substrates, at temperatures from 15 to $24^{\circ} \mathrm{C}$, particularly below $20^{\circ} \mathrm{C}$. All of them were rarely found in winter in either year and were apparently influenced by the SACW, but distribution of $R$. castelnaui was more strongly related to depth. In contrast to these other skates, Zapteryx brevirostris was most abundant at shallow stations, around $35 \mathrm{~m}$ (Fig. 6). It was present at temperatures between 16 and $26^{\circ} \mathrm{C}$, especially around $18-20^{\circ} \mathrm{C}$, and almost exclusively over sandy bottom.

Pagrus pagrus was common at stations 2 and 8 (Fig. 5), where temperatures ranged from 16 to $21^{\circ} \mathrm{C}$. Its association with gravel bottom and greater abundance in summer and autumn made its distribution relatively distinct from that of other species in the sample area.

Although young and adults were found in the area throughout the year, a seasonal distribution was observed for some of the species. Adults from Menticirrhus americanus predominated in winter, in contrast to Cynoscion guatucupa, Orthopristis ruber, and Umbrina canosai adults, that occurred mainly in summer. For all species, but Dules arriga and Paralichthys patagonicus, catches were dominated by young, which increased slightly on the second year. Micropogonias furnieri, Pagrus pagrus, and Squatina guggenheim catches were composed almost exclusively of young.

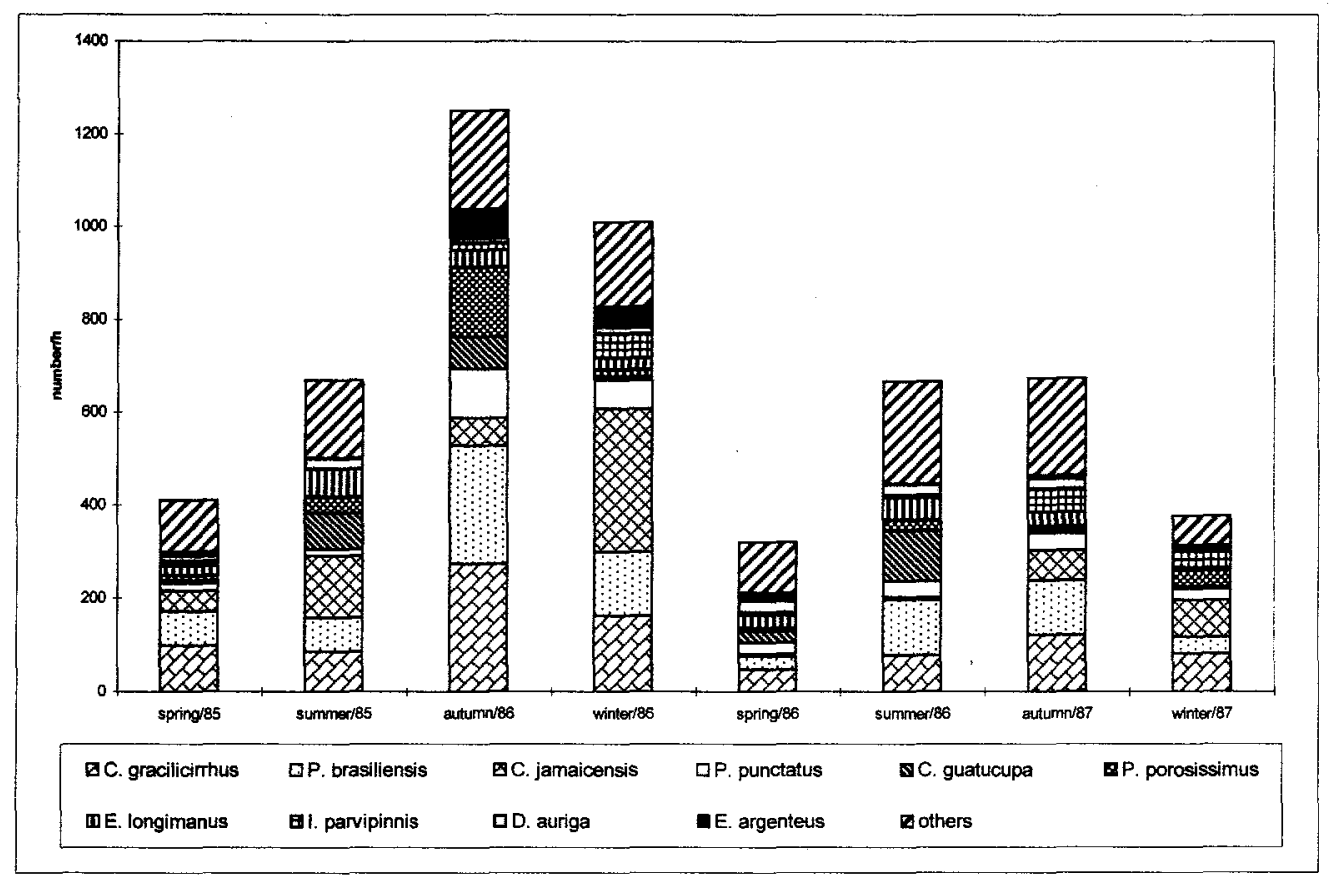

Fig. 3. Seasonal variation in number of individuals by hour for the most abundant species during 1985-87 period. 


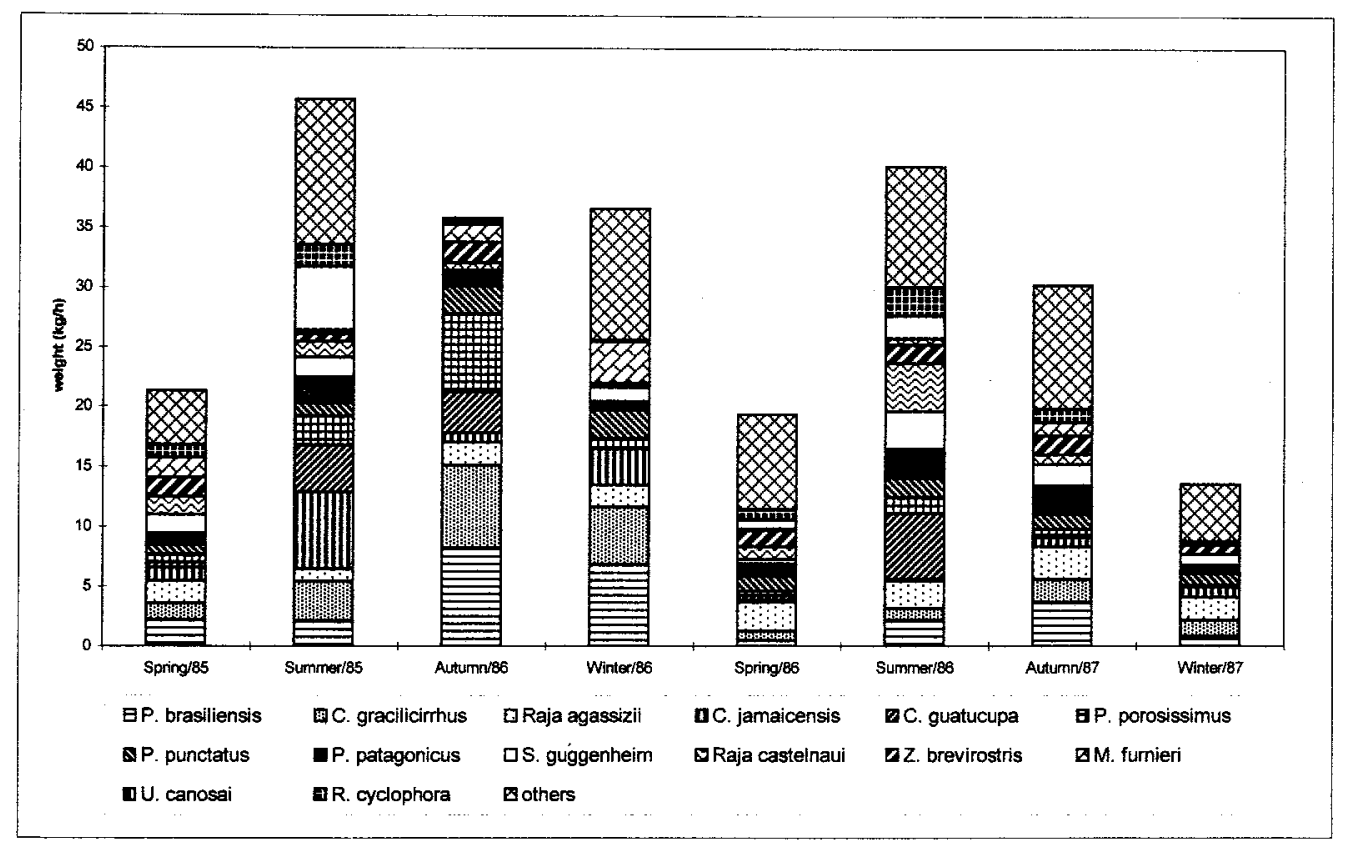

Fig. 4. Seasonal variation of weight $(\mathrm{kg} / \mathrm{h})$ for the most abundant species during 1985-86 period.

Table 3. Dominant species total and relative number, weight $(\mathrm{kg})$ and occurrence for 1985-86, 1986-87 periods and both.

\begin{tabular}{lrrrrrrrrrr}
\hline & \multicolumn{3}{c}{ \% NUMBER } & \multicolumn{3}{c}{ \% WEIGHT } & \multicolumn{3}{c}{ \% OCCURRENCE } \\
\hline & $1985-86$ & $1986-87$ & both & $1985-86$ & $1986-87$ & both & $1985-86$ & $1986-87$ & both \\
\hline & 18.58 & 16.01 & 17.60 & 10.99 & 4.91 & 8.50 & 83 & 78 & 80 \\
Ctenosciaena gracilicirrhus & 16.06 & 14.80 & 15.58 & 12.93 & 6.76 & 10.40 & 72 & 33 & 53 \\
Paralonchurus brasiliensis & 16.34 & 7.58 & 13.02 & 7.61 & 1.90 & 5.28 & 86 & 56 & 69 \\
Cynoscion jamaicensis & 5.86 & 5.77 & 5.82 & 4.43 & 4.96 & 4.64 & 94 & 100 & 97 \\
Prionotus punctatus & 6.46 & 2.04 & 4.79 & 6.96 & 2.23 & 5.02 & 89 & 78 & 83 \\
Porichthys porosissimus & 4.72 & 7.14 & 5.64 & 5.34 & 5.95 & 5.59 & 42 & 44 & 43 \\
Cynoscion guatucupa & 0.85 & 1.81 & 1.21 & 4.47 & 9.12 & 6.38 & 78 & 75 & 76 \\
Raja agassizii & 2.48 & 2.00 & 2.30 & 4.70 & 1.82 & 3.52 & 72 & 44 & 58 \\
Micropogonias furnieri & 0.87 & 3.16 & 1.74 & 2.12 & 3.58 & 2.72 & 72 & 50 & 61 \\
Menticirrhus americanus & 1.90 & 3.99 & 2.69 & 1.42 & 2.92 & 2.04 & 50 & 53 & 51 \\
Dules auriga & 0.73 & 1.00 & 0.83 & 3.41 & 6.29 & 4.59 & 78 & 69 & 74 \\
Paralichthys patagonicus & 4.24 & 5.18 & 4.60 & 0.69 & 0.73 & 0.70 & 72 & 72 & 72 \\
Etropus longimanus & 3.36 & 1.42 & 2.62 & 1.79 & 0.97 & 1.46 & 61 & 39 & 50 \\
Eucinostomus argenteus & 1.74 & 0.89 & 1.42 & 3.09 & 2.20 & 2.72 & 58 & 42 & 50 \\
Orthopristis ruber & 1.05 & 2.30 & 1.53 & 1.74 & 3.47 & 2.45 & 47 & 47 & 47 \\
Psammobatis glansdissimilis & 1.83 & 1.81 & 1.82 & 3.79 & 2.68 & 3.33 & 19 & 14 & 17 \\
Umbrina canosai & 2.22 & 4.75 & 3.18 & 0.48 & 0.99 & 0.69 & 42 & 31 & 36 \\
Isopisthus parvipinnis & 0.29 & 0.83 & 0.49 & 2.23 & 4.36 & 3.11 & 42 & 36 & 39 \\
Raja cyclophora & 0.30 & 0.59 & 0.41 & 2.80 & 5.08 & 3.73 & 36 & 42 & 39 \\
Zapteryx brevirosotris & 0.54 & 3.04 & 1.49 & 0.22 & 1.44 & 0.59 & 33 & 33 & 33 \\
Pagrus pagrus & 0.10 & 0.22 & 0.14 & 3.00 & 5.95 & 4.21 & 33 & 31 & 32 \\
Squatina guggenheim & 0.12 & 0.18 & 0.14 & 2.36 & 5.75 & 3.75 & 33 & 22 & 28 \\
Raja castelnaui & & & & & & & & & \\
& 30056 & 18364 & 48420 & 1340 & 928 & 2268 & 36 & 36 & 72 \\
\hline & & & & & & & &
\end{tabular}



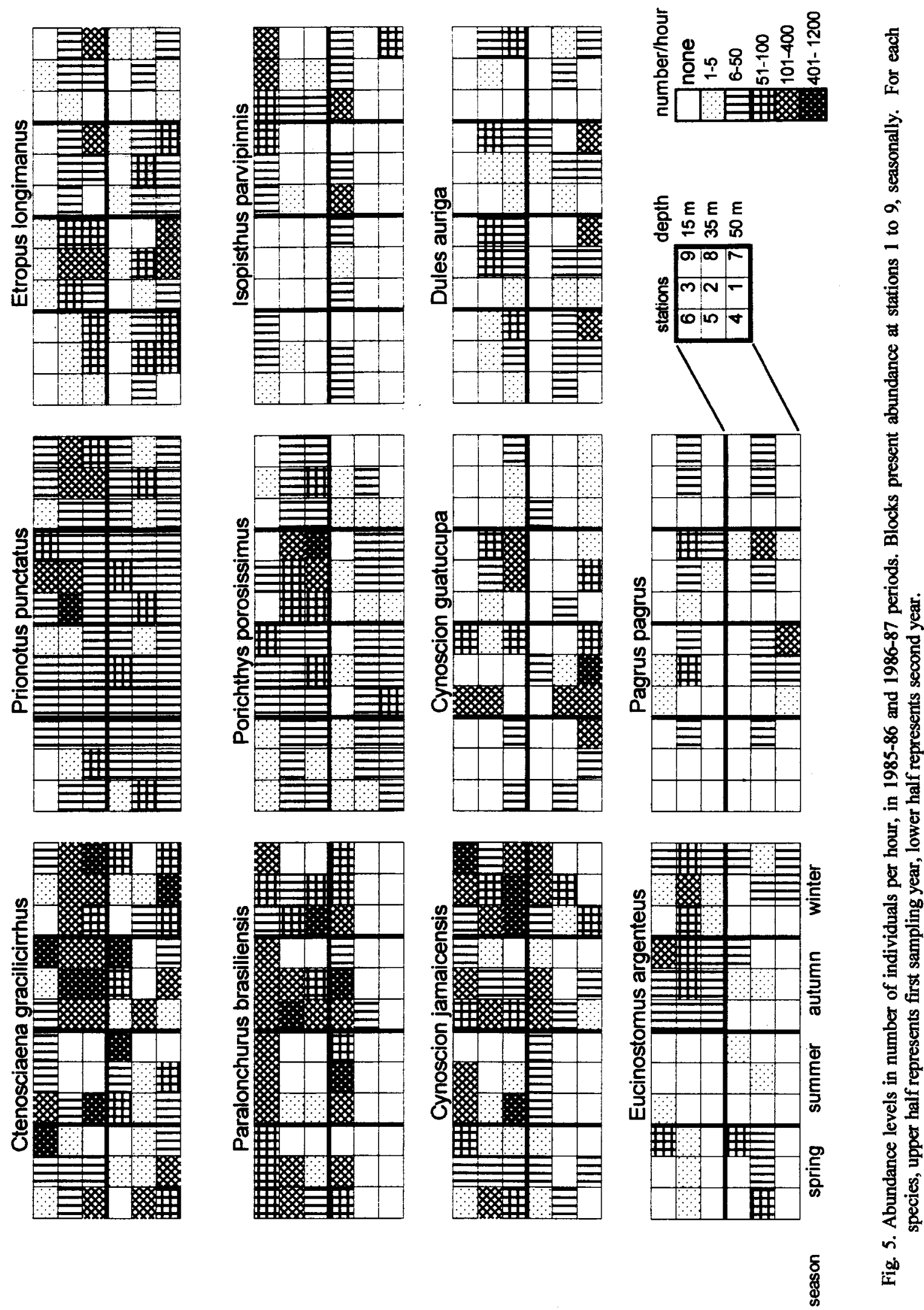

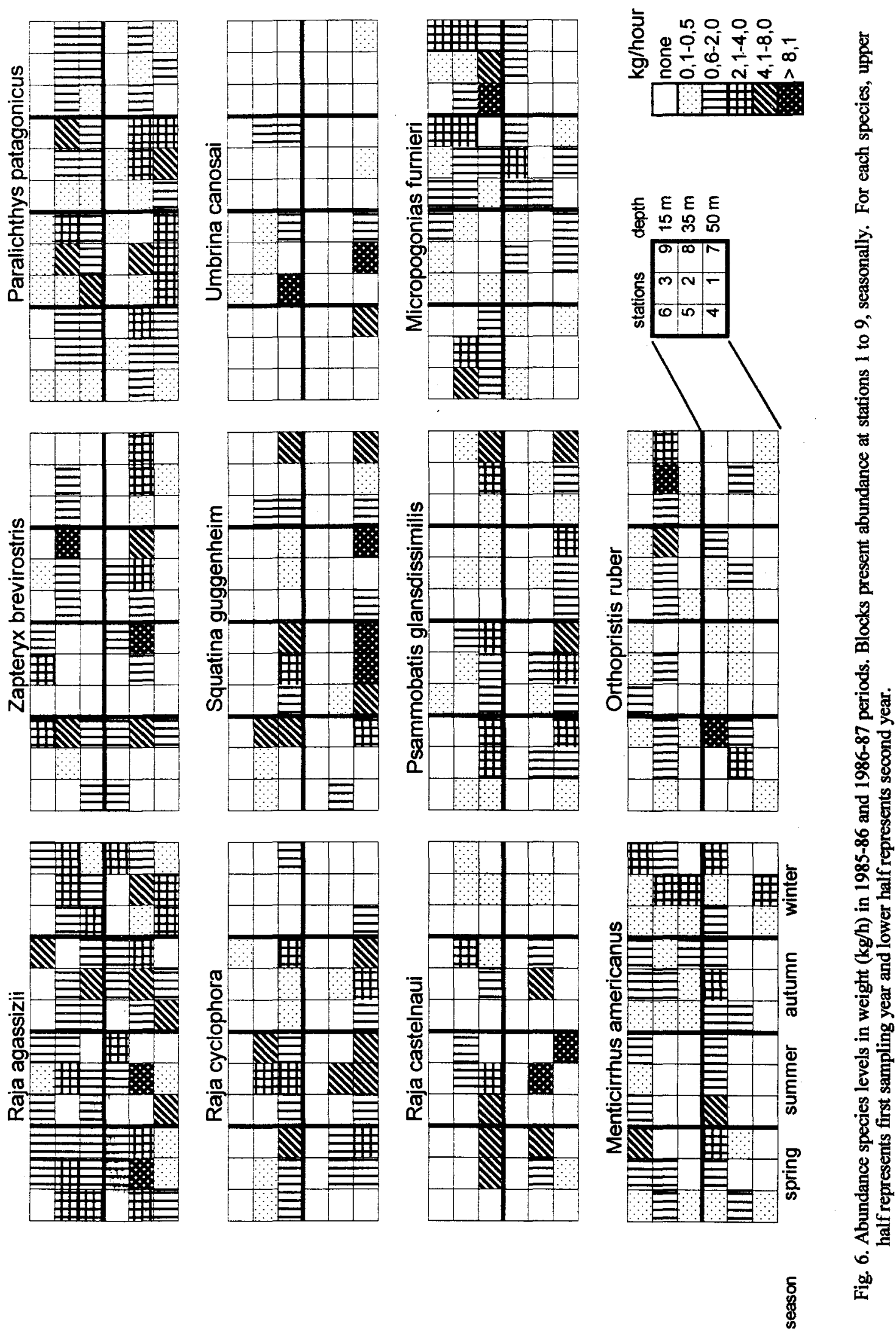
The species distribution indicated the existence of different assemblages in the area, which were clarified with a CANOCO analysis.

\section{Communities}

CCA provides an ordination of species and sites, constrained by environmental variables (Figs 7 and 8). In both years, Axis I was correlated to temperature and depth, while Axis II was related to salinity and organic matter in $1985-86$ period, and to bottom sediment types, in the following year. In the first year, Axes I and II accounted for 21.5 and $6.1 \%$ of the variation, respectively and in the second year they accounted for 19.2 and $8.1 \%$. Axes III and IV accounted for less than $5 \%$ each one and were not considered here (Tab. 4). Axis I represents a gradient from shallower and warmer stations (on the positive side of the axis) to deeper and colder ones (on the negative) (Figs 7a, 8a). Axis II runs from sand and sandy-clay localities on the negative side of the axis to sandy-shell, rich organic stations on the positive side. The species scores along Axes I and II show their association with the localities and the environmental gradients (Figs $7 b, 8 b$ ). Results of the ordination analyses, relating abundance of the dominant species to the environmental factors, identified three distinct assemblages of species in the area. Since communities composition was similar to that observed elsewhere by Longhurst \& Pauly (1987), their community classification was adopted here.
Sciaenids were the most widely distributed family down to $50 \mathrm{~m}$ depth, with three species Ctenosciaena gracilicirrhus, Paralonchurus brasiliensis, and Cynoscion jamaicensis contributing almost $50 \%$ of the number and more than $20 \%$ in weight of the total catches (Tab. 3). These species, together with other sciaenids associated with warm waters and sand and sandy-mud sediments, constituted the Tropical Scianid Community. This group accounted for $>60 \%$ of the numbers and $40 \%$ of the biomass in the total catch. Species belonging to other families, such as Prionotus punctatus, Zapteryx brevirostris, and Raja agassizii, overlapped in distribution with the Tropical Scianid group, but were less affected by water masses.

Species such as Eucinostomus argenteus and Orthopristis ruber were associated with Coastal Water, but had a more restricted distribution, occurring at shallow and sandy-shell bottom stations, in the northern portion of the area. Many Haemulidae and Serranidae species also associated with this kind of substratum, but were not classified among the most important species because of their low abundance. These species constituted the Gerreid-Haemulid Community and correspond to the Lutjanid Community of Longhurst \& Pauly (1987). They represented $6 \%$ by number and weight of the total catch. In the ordination space, the Tropical Sciaenid and Gerreid-Haemulid communities were associated with the positive side of Axis I, but were split by Axis II.

Table 4. Correlation matrix relating species axis to environmental variables (Interset correlations) and eigenvalues (\%).

\begin{tabular}{lrrrr}
\hline & Axis I & Axis II & Axis III & Axis IV \\
\hline \multicolumn{1}{c}{ 1985-1986 } & & & & \\
Depth & -0.81 & 0.288 & -0.284 & -0.016 \\
Temperature & 0.781 & 0.197 & -0.257 & 0.254 \\
Salinity & 0.001 & 0.598 & -0.168 & -0.458 \\
Organic matter & 0.2 & -0.357 & -0.694 & 0.169 \\
eigenvalues & 21.5 & 6.1 & 3.5 & 1.3 \\
$\quad$ & & & & \\
$\quad$ 1986-1987 & & & & \\
Depth & -0.75 & -0.123 & 0.089 & 0.195 \\
Temperature & 0.579 & 0.232 & 0.202 & -0.173 \\
CaCO3 & -0.244 & 0.414 & -0.013 & 0.615 \\
Sand & -0.416 & 0.47 & -0.255 & -0.405 \\
argila & 0.181 & -0.369 & 0.56 & 0.19 \\
eigenvalues & 19.2 & 8.1 & 3.3 & 2.6 \\
\hline
\end{tabular}




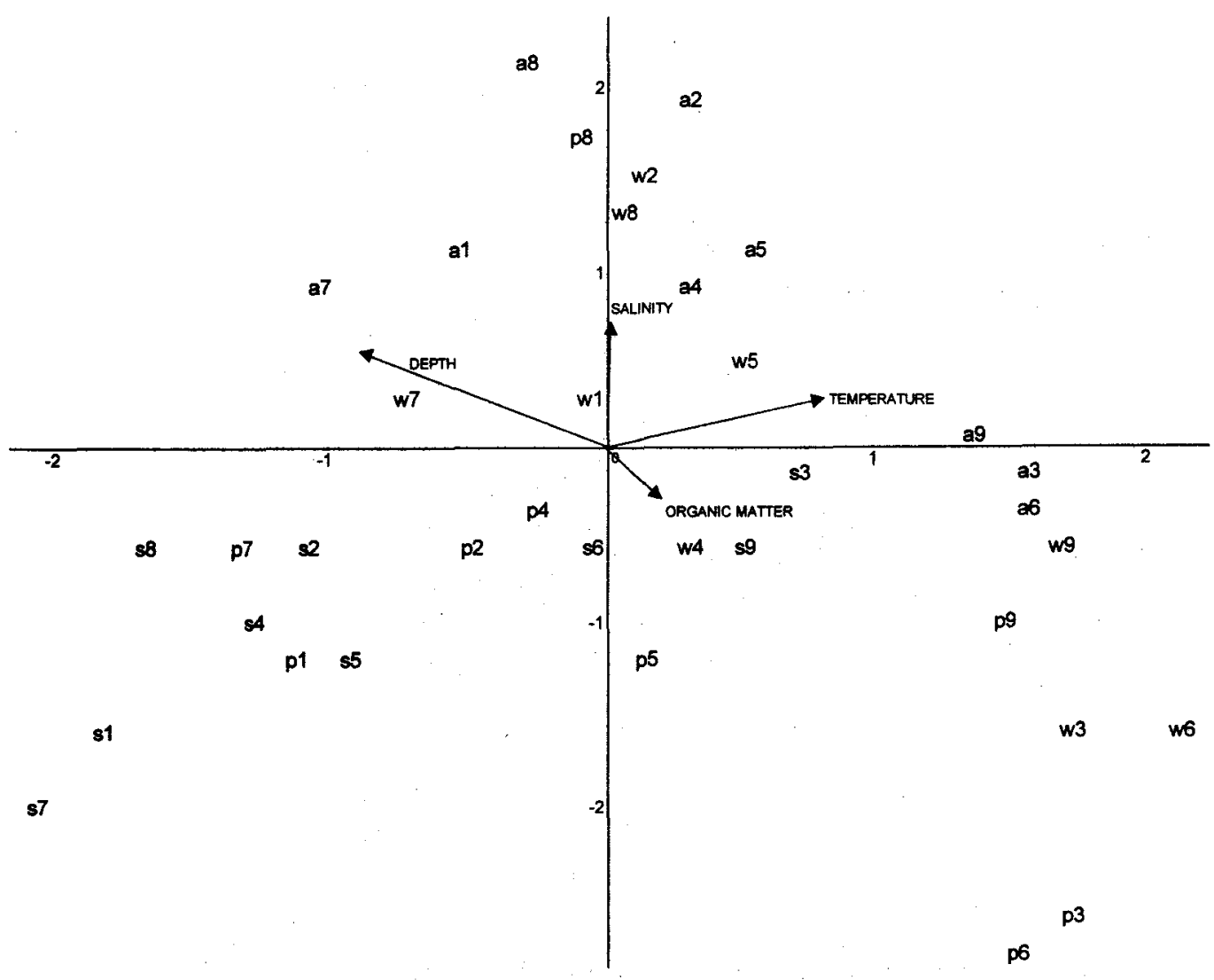

Fig. 7a. Ordination plot of environmental variables and stations (1 to 9) for 1985-86 seasons. Spring (p) Summer (s) Autumn (a) Winter (w)

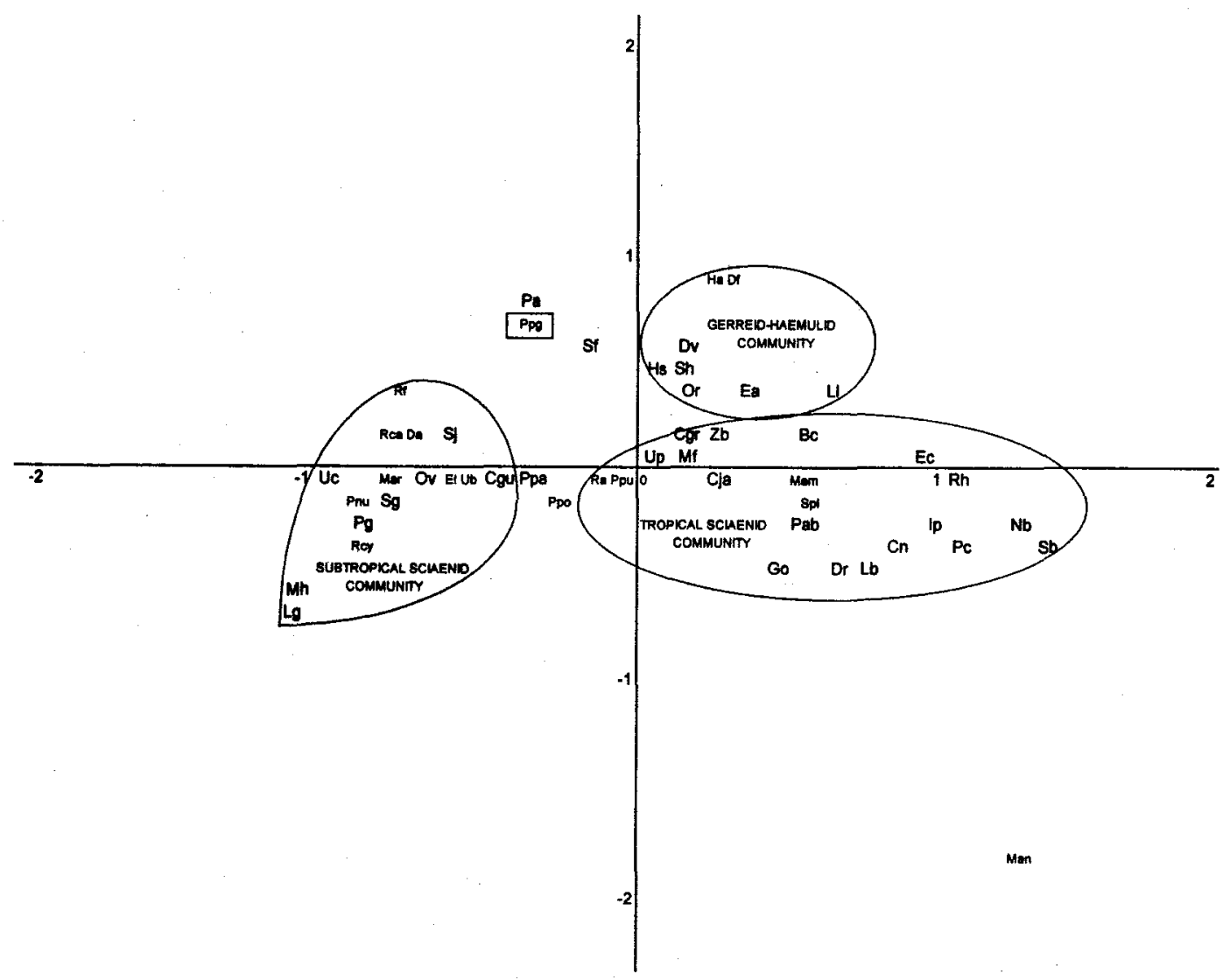

Fig. 7b. Species scores on Axis I and II, during 1985-86. Species codes are found in Table 1. 


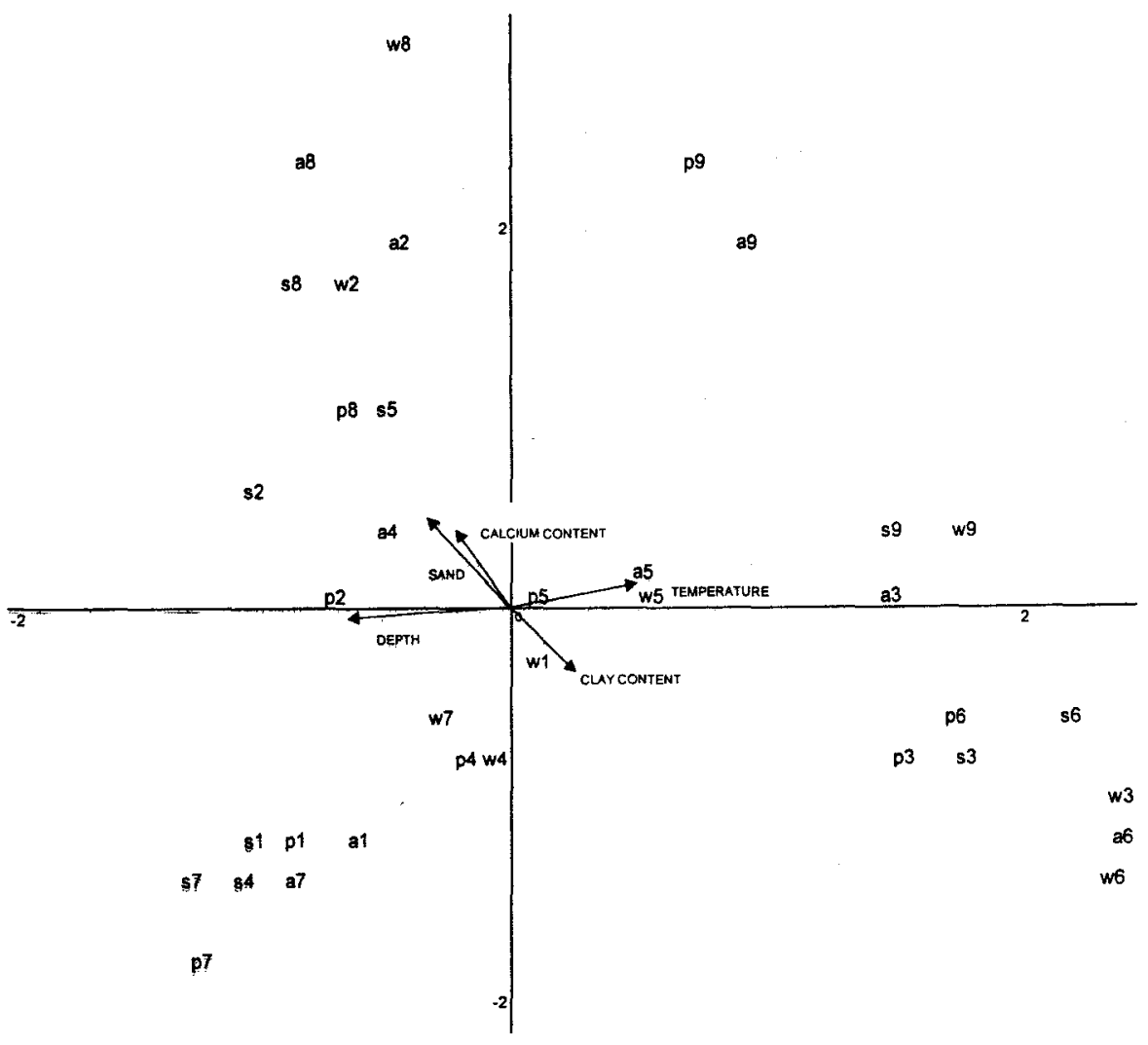

Fig 8a. Ordination plot of environmental variables and station (1 to 9), for 1985-87 seasons. Spring (p) Summer (s) Autumn (a) Winter (w)

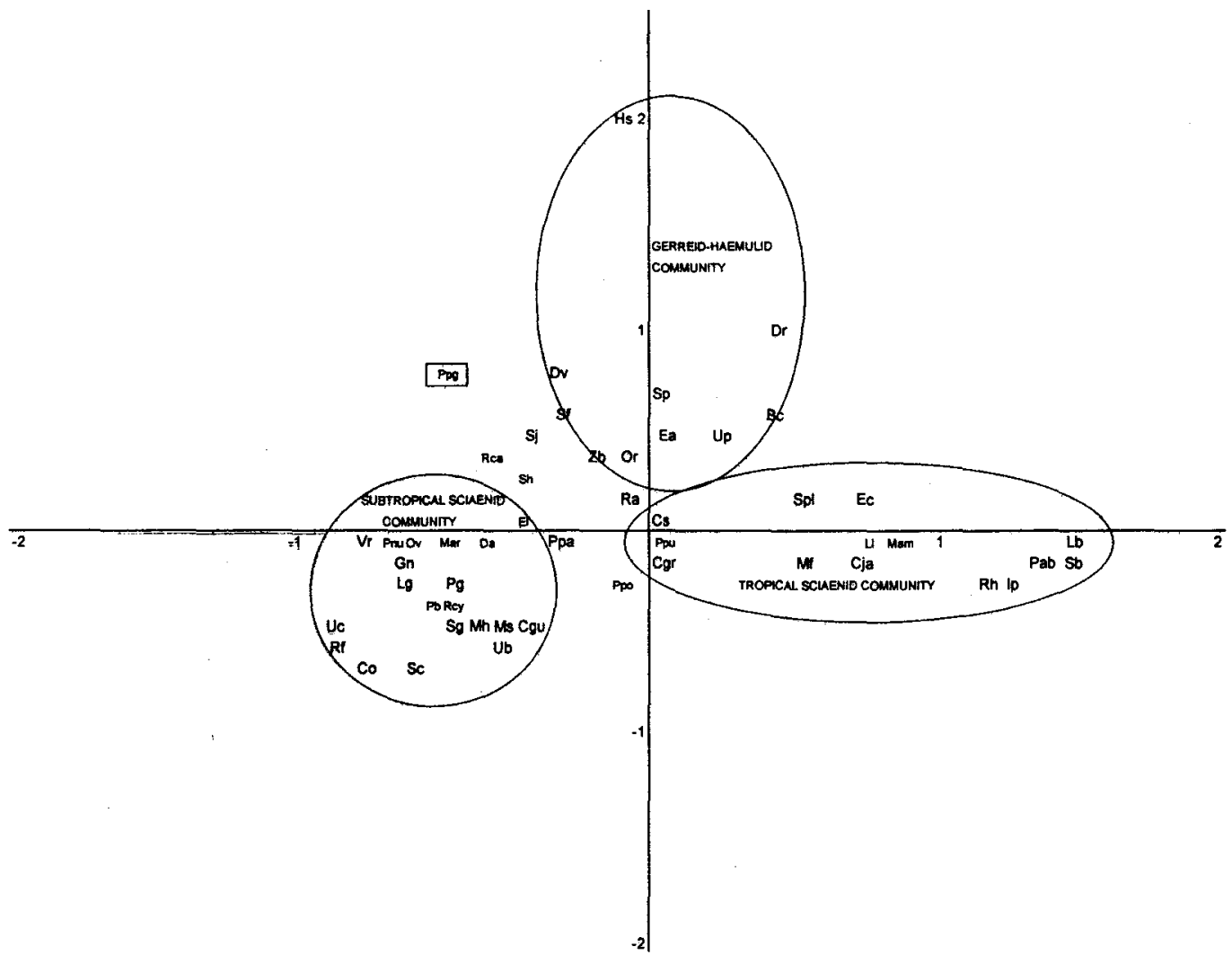

Fig. 8b. Species scores on Axis I and II, during 1986-87 period. Species codes are found in Table 1. 
At depths around $50 \mathrm{~m}$, the sciaenids Cynoscion guatucupa and Umbrina canosai, together with Dules auriga, Merluccius hubbsi, Raja cyclophora, Etropus longimanus, and Prionotus nudigula, among others, were closely associated with SACW. They comprised the Subtropical Sciaenid Community and accounted for $15 \%$ of number and weight of the demersal icthyofauna in the area.

Temperature together with depth and substratum were the main environmental factors structuring the major assemblages. However, some species such as Squatina guggenheim, Raja castelnaui, Paralichthys patagonicus, and Porichthys porosissimus were distributed according to depth rather than by water mass movements. In addition to three main assemblages, the Pagrus pagrus distribution was distinct from all others. Its position in the multivariate space was clearly isolated from any other assemblages (Figs $7 \mathrm{~b}, 8 \mathrm{~b}$ ), and may indicate the existence of a unique life history strategy for this species.

\section{Discussion}

Many authors consider dominant species those which together contribute $>90 \%$ of the total number of individuals (Dahlberg \& Odum, 1970; Horn, 1980), while others also consider frequency of occurrence (Riehards \& Castagna, 1970; Colvocoresses \& Musick, 1984) or biomass (Mahon \& Balon, 1977) to be important. According to YánezArancibia (1986), in tropical regions, the definition of a species as dominant has to consider at least three ecological factors: abundance in number and weight, and frequency of oceurrence. Therefore, all of these variables were considered here.

The Ubatuba ecosystem is an important habitat for young fish. Most of the species use the area for growing and maturing but not spawning. Only three of the species collected in this study (M. americanus, $P$. patagonicus, and $P$. glansdissimilis) reproduce in the area (Vazzoller et al, 1989 a, b*; Louro, 1995).

Sea temperature is the major factor in the division of marine faunas (Lowe-McConnell, 1987). The tropical fauna lies between the $20^{\circ} \mathrm{C}$ isotherms

(*) Vazzoler, A. E. A. de M.; Santoro-Mazagão, E. C. \& Lizama, M. de los A. P. 1989a. Função reprodutiva dos Sciaenidae em ecossistema tropical costeiro do estado de São Paulo. In: SIMPÓSIO SOBRE OCEANOGRAFIA, I. São Paulo, 1989. Resumos. São Paulo, IOUSP. p 76.

Vazzoler, A. E. A. de M.; Silveira, M. M. C.; Lizama, M. de los A. P. \& Santoro-Mazagão, E. C. 1989b. Função reprodutiva dos Pleuronectiformes em ecossistema tropical costeiro do estado de São Paulo. In: SIMPÓSIO SOBRE OCEANOGRAFIA, I. São Paulo, 1989. Resumos. São Paulo, IOUSP. p 72. for surface water temperatures at the coolest time of year, flanked on either side by subtropical faunas living where the water temperature does not fall bellow $16-18^{\circ} \mathrm{C}$. Marine fish faunas are also greatly affected by depth, current systems, salinity, oxygenation, availability of food, and many other factors (Lowe-McConnell, op. cit.). Considering the ecological attributes of tropical fish communities and their responses to environmental conditions, LoweMcConnell (op. cit.) points out that seasonality, even in tropical waters, is a major factor affecting many aspects of the community. Longhurst \& Pauly (1987) also consider seasonality an important factor in tropical oceans.

Ichthyofauna has been divided into zones based on depth and substratum type. On the Continental Shelf of Guyana, Lowe-McConnell (1962) reported zones of "brown, golden, silver and red fish". Longhurst (1965) and Maurin (1968) emphasized the importance of the thermocline as a biological barrier, and suggested a strong association between the presence and abundance of tropical species and the existence of waters with bottom temperatures around $20^{\circ} \mathrm{C}$. Longhurst (op. cit.) proposed a division of demersal fish into Sciaenid, Sparid and Deep Communities, and eurybathic species. The main assemblages of fishes recognized by computer analyses off West Africa are also found in the western Atlantic and appear again in the IndoPacific (Lowe-McConnell, 1987). In a recent publication Longhurst \& Pauly (1987) confirmed the occurrence of four communities in tropical regions: Tropical Sciaenid, Subtropical Sciaenid, Lutjanid, and Sparid. Nevertheless, no references to these communities were found in the southern Brazilian waters.

The area included in the present study is clearly a transition zone, with elements of tropical and temperate faunas. The tropical species grouped in the Tropical Sciaenid Community dominate. Previous studies have noted the coexistence of Ctenosciaena gracilicirrhus, Paralonchurus brasiliensis, and Cynoscion jamaicensis (Vazzoler, 1975; BenvegnuLé, 1978; Cunningham, 1983; Braga \& Goitein, 1984), as well as their importance along the southeastern Brazilian coast to latitude $32^{\circ} \mathrm{S}$ (Costa, 1977; Cunningham, 1978; Facchini, 1995). In Santos Bight $\left(24^{\circ} \mathrm{S}\right)$, at depths up to $20 \mathrm{~m}$, Ribeiro Neto (1989) also observed the dominance of sciaenids, with 20 species reaching more than $30 \%$ in number and weight, although the dominant species was Stellifer rastrifer. Between $22^{\circ}$ and $29^{\circ} \mathrm{S}$, in the zone up to $50 \mathrm{~m}$ depth, Facchini (1995) reported the same sciaenid species found on the Ubatuba inner shelf as dominants. Among these species, only Cynoscion guatucupa, Umbrina canosai, Micropogonias furnieri, and Ctenosciaena gracilicirrhus were important beyond $50 \mathrm{~m}$. 
The Subtropical Sciaenid Community gains importance on the external domain (Natali Neto, 1994), and southward, where SACW is closer to the coast and lower water temperatures are found. Between $29^{\circ}$ and $33^{\circ} \mathrm{S}$, Vazzoler (1975) referred to Cynoscion guatucupa and Umbrina canosai as the most abundant sciaenids, while Benvegnu-Lé (1978) reported the occurrence of these species at greater average depths and lower temperatures than that for Tropical Sciaenid species.

At Cabo Frio $\left(23^{\circ} \mathrm{S}, 42^{\circ} \mathrm{W}\right)$, where the penetration of the SACW promotes an upwelling during spring and summer, Fagundes Netto and Gaelzer (1991) noted the presence of Dules auriga, Etropus longimanus, and Prionotus nudigula throughout the year, associated with depths around 45 and $60 \mathrm{~m}$ and temperatures from 14 to $22^{\circ} \mathrm{C}$. In that area Etropus longimanus was the most abundant species in number of individuals, while Cynoscion guatucupa and Umbrina canosai were less abundant. The authors also reported the occurrence of Ctenosciaena gracilicirrhus, Cynoscion jamaicensis, Micropogonias furnieri, and Prionotus punctatus, during autumn and winter periods, when warmer waters predominated. Their results suggest that the ichthyofaunal elements from $45-60 \mathrm{~m}$ move to $30-45 \mathrm{~m}$, during the upwelling period. Similar dynamics was observed on the Ubatuba's shelf, although to a lesser degree.

Figueiredo (1981) identified the south western Atlantic as a marine zoogeographic province based on a series of endemic species he found there. The endemic species, such as Cynoscion guatucupa, Umbrina canosai, and Prionotus nudigula, were observed in colder and deeper waters than their tropical counterparts (Cynoscion jamaicensis, Ctenosciaena gracilicirrhus, and Prionotus punctatus, respectively). While these tropical species occurred throughout the year, the endemic species reached the Ubatuba inner shelf mainly in summer, with the inward movement of SACW.

The Lutjanid Community is dominant in the Antilles and Caribbean (Longhurst \& Pauly, 1987). Similar of species were also found in the Gulf of Mexico (Yáñez-Arancibia et al., 1985). Comparing eastern and western Atlantic Communities, LoweMcConnell (1987) considers that the Lutjanid Community assumes much greater importance in the Caribbean than off West Africa, since there are much larger areas of hard bottom in the western Atlantic. Species from this family have great importance for fisheries along the northeastern coast of Brazil (Fonteles Filho, 1969; Paiva et al., 1971), but their occurrence decreases southward. At Cabo Frio, Fagundes Netto and Gaelzer (1991) noted the association of Orthopristis ruber and Eucinostomus argenteus in the catches, but did not record any Lutjanidae species. Cunningham (1983) found Gerreidae and Pomadasyidae to be among the most important families in bays near Ubatuba. The three Gerreidae and five Pomadasyidae species present accounted for more than $11 \%$ of the individuals, while Lutjanidae was unimportant.

At Santos Bight, Ribeiro Neto (1989) reported five Gerreidae and seven Pomadasyidae species as relatively abundant, whereas only one species of Lutjanidae rarely occurred. Between $22^{\circ}$ and $29^{\circ} \mathrm{S}$, Facchini (1995) also emphasized the importance of Haemulidae (5\% of individuals) in the catches, and to a smaller degree, of Gerreidae, Diodontidae, Tetraodontidae, and Serranidae; Lutjanidae were rare. These results show that the Lutjanid Community is replaced by Gerreidae and Haemulidae species, as one moves south.

The Sparid Community, observed in other areas (Longhurst \& Pauly, 1987), could not be characterized as an assemblage on the Ubatuba inner shelf. Nevertheless, Pagrus pagrus was among the 10 most abundant species of the outer shelf, and reached almost $5 \%$ in number and $2 \%$ in weight of the total catches from $50 \mathrm{~m}$ to $100 \mathrm{~m}$ (Natali Neto, 1994). The Pagrus pagrus is associated with hard bottom (Manooch III \& Hassler, 1978), which is a rare habitat in the study area. However, this species is increasing in importance in the fishery along the Brazilian south coast (Silva, 1996).

Although changes in species composition and relative abundance occurred at different levels, three communities were always present in the Ubatuba area. Facchini's (1995) recent study showed their presence to $29^{\circ} \mathrm{S}$.

Bianchi (1991) suggested that when the depth range is wide enough to include areas where different water layers impinge on the shelf slope, the greatest changes in species composition are depth related. However, within each water layer, other factors such as temperature and sediment type become relevant. Pires (1992) studied the benthic megafauna in continental shelf waters of Ubatuba and reported depth and water mass dynamics as main factors in the division of species assemblages. On the inner shelf, depth and water masses were also important in the determination of the fish communities.

Understanding the relationships between physical factors of the environment and changes in species composition is important. In a long-term study of groundfish assemblages, Gomes et al. (1995) considered that, when the entire community is subjected to prolonged adverse conditions, the sequence of species reactions should be roughly correlated with species abundance on the shelf, with the most widespread and abundant species reacting later. Thus, changes in the distribution patterns of less abundant species could anticipate changes at community level. Gomes et al. (op. cit.) found it difficult to account for the observed decline of many species (especially noncommercial ones) with arguments that revolve strictly around exploitation 
and decimation by fisheries. They suggested that changing environmental conditions were at least an important contributing factor underlying the observed trends in community composition and abundance.

Overholtz \& Tyler (1985) point out the importance of investigating the long-term temporal scale of community dynamics, so that ecologists and managers can function in terms of ecological time. Since this study was conducted for only a two-year period, community trends could not be determined. However, it identifies changing environmental conditions that have to be taken into consideration for future management purposes.

\section{Acknowledgments}

This paper is part of a thesis by the senior author submitted in partial fulfillment of the requirements for the M.Sc. Degree at Instituto Oceanográfico - University of São Paulo, which was partially supported by CAPES, CNPq and FAPESP. Financial support from CIRM (Comissão Interministerial para os Recursos do Mar) is gratefully acknowledged. We are especially appreciative of the reviews given to this paper by an anonymous reviewer. His efforts have helped to produce an improved manuscript.

\section{References}

Benvegnu-Lé, G. de Q. 1978. Distribuição dos peixes teleósteos marinhos demersais na plataforma continental do Rio Grande do Sul. Tese de doutorado. Universidade de São Paulo, Instituto de Biociências. 94p.

Bianchi, G. 1991. Demersal assemblages of the continental shelf and slope edge between the Gulf of Tehuantepec (Mexico) and the Gulf of Papagayo (Costa Rica). Mar. Ecol. Prog. Ser., 73(2-3):121-140.

Braga, F. M. S. \& Goitein, R. 1984. Lista prévia das espécies de peixes demersais na região da Ilha Anchieta (Lat. 23 $33^{\prime} \mathrm{S}$ - Long. $45^{\circ} 05^{\prime} \mathrm{W}$ ), Ubatuba, litoral norte do Estado de São Paulo, Brasil. Naturalia, S Paulo, 9:61-72.

Castro-Filho, B. M. de; Miranda, L. B. de \& Miyao, S. Y. 1987. Condições hidrográficas na plataforma continental ao largo de Ubatuba: variações sazonais e em média escala. Bolm Inst. oceanogr., S Paulo, 35(2):135-151.
Colvocoresses, J. A. \& Musick, J. A. 1984. Species associations and community composition of middle Atlantic bight continental shelf demersal fishes. Fish. Bull., U.S., 82(2):295313.

Costa, C. C. C. 1977. Aspectos do ciclo de vida e bionomia de Ctenosciaena gracilicirrhus (Metzelaar, 1919) da plataforma continental do Rio Grande do Sul, Brasil. Dissertação de mestrado. Universidade de São Paulo, Instituto Oceanográfico. 63p.

Cunningham, P. T. M. 1978. Bionomia e ciclo de vida de Ctenosciaena gracilicirrhus (Metzelaar, 1919) na plataforma continental brasileira entre as latitudes de $22^{\circ} 10^{\prime} \mathrm{S}$ e $30^{\circ} \mathrm{S}$. Dissertação de mestrado. Universidade de São Paulo, Instituto Oceanográfico. 106p.

Cunningham, P. T. M. 1983. Estudo comparativo da ictiofauna da costa oeste e Enseada das Palmas da Ilha Anchieta, Enseada do Flamengo e Enseada da Fortaleza (Lat $23^{\circ} 29^{\prime} \mathrm{S}-23^{\circ} 33^{\prime} \mathrm{S}$, Long $45^{\circ} 03^{\prime} \mathrm{W}-45^{\circ} 09^{\prime} \mathrm{W}$ ), Ubatuba, Estado de São Paulo - Brasil. Tese de doutorado. Universidade de São Paulo, Instituto Oceanográfico. 133p.

Dahlberg, M. D. \& Odum, E. P. 1970. Annual cycles of species ocurrence, abundance and diversity in Georgia estuarine fish populations. Am. Midl. Naturalist, 83(2): 382-392.

Facchini, B. H. 1995. Ecologia de associações de peixes teleósteos demersais da plataforma continental sudeste do Brasil, de Cabo de São Tomé a Torres $\left(22^{\circ} 04^{\prime}-29^{\circ} 21^{\prime} \mathrm{S}\right)$. Tese de doutorado. Universidade de São Paulo, Instituto Oceanográfico. $228 \mathrm{p}$.

Fagundes Netto, E. B. \& Gaelzer, L. R. 1991. Associações de peixes bentônicos e demersais na região de Cabo Frio, RJ, Brasil. Nerítica, Curitiba, 6(1-2):139-156.

Figueiredo, J. L. de 1981. Estudo das distribuições endêmicas de peixes da Província Zoogeográfica Marinha Argentina. Tese de doutorado. Universidade de São Paulo, Instituto de Biociências. 121p.

Fonteles Filho, A. A. 1969. Estudo preliminar sobre a pesca do pargo, Lutjanus purpureus Poey, no nordeste brasileiro. Arq. Ciênc. Mar, Fortaleza, 9(1):83-88. 
Gomes, M. C.; Haedrich, R. L. \& Villagarcia, M. G. 1995. Spatial and temporal changes in the groundfish assemblages on the north-east Newfoundland/Labrador shelf, north-west Atlantic, 1978-1991. Fish. Oceanogr., 4(2):85101.

Horn, M. H. 1980. Diel and seasonal variation in abundance and diversity of shallow-water fish populations in Morrow Bay, California. Fish. Bull., U. S., 78(3):759-770.

Longhurst, A. R. 1965. A survey of the fish resources of the eastern Gulf of Guinea. J. Cons. int. perm. Explor. Mer, 29(3):302-334.

Longhurst, A. R. \& Pauly, D. 1987. Ecology of tropical oceans. San Diego, Academic Press. $407 \mathrm{p}$.

Louro, M. P. 1995. Estratégias e táticas reprodutivas de elasmobrânquios no ecossistema de Ubatuba, SP, Brasil. Dissertação de mestrado. Universidade de São Paulo, Instituto Oceanográfico. 2v.

Lowe-McConnell, R. H. 1962. The fishes of the British Guiana Continental Shelf, Atlantic coast of South America, with notes on their natural history. Zool. J. Linn. Soc., 44(301):669-700.

Lowe-McConnell, R. H. 1987. Ecological studies in tropical fish communities. Cambridge, Cambridge University Press. 382p.

Mahon, R. \& Balon, E. K. 1977. Ecological fish production in Long Pond, a lakeshore lagoon on Long Point, Lake Erie. Environ. Biol. Fishes, 2(3):261-284.

Manooch III, C. S. \& Hassler, W. W. 1978. Synopsis of biological data on the red porgy, Pagrus pagrus (Linnaeus). NOAA Tech. Rep. NMFS Circ., 412:1-19.

Maurin, C. 1968. Écologie ichthyologique des fonds chalutables Atlantiques (de la Baie IbéroMarocaine a la Mauritanie) et de la Méditerranée occidentale. Revue Trav. Inst. Pêches marit., 32:1-147.

Natali Neto, J. F. 1994. Ictiofauna do ecossistema tropical marinho de Ubatuba $\left(23^{\circ} 36^{\prime}-24^{\circ} 22^{\prime} \mathrm{S}\right.$; $\left.44^{\circ} 33^{\prime} \mathrm{S}-45^{\circ} 08^{\prime} \mathrm{W}\right)$, SP - Brasil, entre 50 e 100 m de profundidade: composição, distribuição, abundância e diversidade. Dissertação de mestrado. Universidade de São Paulo, Instituto Oceanográfico. $2 \mathrm{v}$.
Nonato, E. F.; Amaral, A. C. Z. \& Figueiredo, J. L. 1983. Contribuição ao conhecimento da fauna de peixes do litoral norte do Estado de São Paulo. Bolm Inst. oceanogr., S Paulo, 32(2): 143-152.

Overholtz, W. J. \& Tyler, A. V. 1985. Long-term responses of the demersal fish assemblages of Georges bank. Fish. Bull., U. S., 83(4): 507520.

Paiva, M. P.; Bezerra, R. C. F. \& Fonteles Filho, A. A. 1971. Tentativa de avaliação dos recursos pesqueiros do nordeste brasileiro. Arq. Ciênc. Mar, Fortaleza, 11(1):1-43.

Pires, A. M. S. 1992. Structure and dynamics of benthic megafauna on the continental shelf offshore of Ubatuba, southeastern Brazil. Mar. Ecol. Prog. Ser., 86(1):63-76.

Pires-Vanin, A. M. S. \& Matsuura, Y. 1993. Estrutura e função do ecossistema de plataforma continental da região de Ubatuba, estado de São Paulo: uma introdução. Publção esp. Inst. oceanogr., S Paulo, (10):1-8.

Pires-Vanin, A. M. S.; Rossi-Wongtschowski, C. L. D. B.; Aidar, E.; Mesquita, H. S. L.; Soares, L. S. H.; Katsuragawa, M. \& Matsuura, Y. 1993. Estrutura e função do ecossistema de plataforma continental da região de Ubatuba, Estado de São Paulo: síntese dos resultados. Publção esp. Inst. oceanogr., S Paulo, (10):217231.

Ribeiro Neto, F. B. 1989. Estudo da comunidade de peixes da Baía de Santos, SP. Dissertação de mestrado, Universidade de São Paulo, Instituto Oceanográfico. 196p.

Richards, C. E. \& Castagna, M. 1970. Marine fishes of Virginia's eastern shore (inlet and marsh, seaside waters). Chesapeake Sci., 11(4):235248.

Rocha, G. R. A. 1990. Distribuição, abundância e diversidade da ictiofauna na região de Ubatuba, SP $\quad\left(23^{\circ} 20^{\prime} \mathrm{S}-24^{\circ} 00^{\prime} \mathrm{S} ; \quad 44^{\circ} 30^{\prime} \mathrm{W}-45^{\circ} 30^{\prime} \mathrm{W}\right)$, Brasil. Dissertação de mestrado. Universidade de São Paulo, Instituto Oceanográfico. 2v.

Rossi-Wongtschowski, C. L. D. B. \& Paes, E. T. 1993. Padrões espaciais e temporais da comunidade de peixes demersais do litoral norte do estado de São Paulo - Ubatuba, Brasil. Publção esp. Inst. oceanogr., S Paulo, (10):169188. 
Silva, A. O. A. da 1996. Idade, crescimento, mortalidade e aspectos reprodutivos do pargo, Pagrus pagrus (Teleostei: Sparidae), na costa do Estado de São Paulo e adjacências. Dissertação de mestrado. Universidade de São Paulo, Instituto Oceanográfico. 116p.

ter Braak; C. J. F. 1990. CANOCO - a FORTAN program for canonical community ordination by (partial) (detrended) (canonical) correspondence analysis and redundance analysis (version 3.10). Wageningen, ITI-TNO.

Vazzoler, G. 1975. Distribuição da fauna de peixes demersais e ecologia dos Sciaenidae da plataforma continental brasileira, entre as

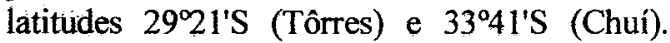
Bolm Inst. oceanogr., S Paulo, 24:85-169.
Yánez-Arancibia, A.; Sánchez-Gil, P.; Villa-LobosZapata, G. J. \& Rodriguez-Capetillo, R. 1985. Distribución y abundancia de las especies dominantes en las poblaciones de peces de la plataforma continental mexicana del Golfo de México. In: Yáñez-Arancibia, A. ed. Recursos pesqueros potenciales de México: la pesca acompañante del camarón. México, U.N.A.M., 1985. p. 315-397.

Yánez-Arancibia, A. 1986. Ecologia de la zona costera: análisis de siete tópicos. México, A. G. T. Editor. 189p.

(Manuscript received 25 November 1997; revised 27 July 1998; accepted 28 September 1988) 